Kirschman, J. C. \& Coniglio, J. G. (1961). F. biol. Chem. 236, 2200.

McLean, J. R. \& Beveridge, J. M. R. (1952), F. Nutr. 47, 4 I.

Mann, G. V. (1960). Fed. Proc. 19, 15.

Mann, G. V., Andrus, S. B., McNally, A. \& Stare, F. J. (1953). Y. exp. Med. 98, 195.

Marks, P. A., Gellhorn, A. \& Kidson, C. (1960). F. biol. Chem. 235, 2579.

Mead, J. F. (1960). Amer. F. clin. Nutr. 8, 55.

Nunn, L. C. A. \& Smedley-MacLean, I. (1938). Biochem. F. 32, 2178.

Schwarz, K., Bieri, J. G., Briggs, G. M. \& Scott, M. L. (1957). Proc. Soc. exp. Biol., N.Y., 95, 621.

Söderhjelm, L. (1962). F. Nutr. 78, 438 .

Stetten, DeW. Jr. \& Salcedo, J. Jr. (I945). F. Nutr. 29, I67.

Valberg, L. S., Young, R. A. \& Beveridge, J. M. R. (1959). Canad. J. Biochem. 37, 493.

Wells, V. M. \& Bronte-Stewart, B. (1963). Brit. med. Y. i, 577.

Williams, M. A. \& Scheier, G. E. (เ96I). F. Nutr. 74, 9 .

Witten, P. W. \& Holman, R. T. (1952). Arch. Biochem. Biophys. 4I, 266.

27 Fuly, Second Session

Chairman : Professor George H. Beaton, PhD, Department of Nutrition, School of Hygiene, University of Toronto

\title{
Interrelationships of nutrients: Chairman's opening remarks
}

\author{
By G. H. Beaton, Department of Nutrition, School of Hygiene, University of Toronto, \\ Toronto, Canada
}

The study of nutrient interrelationships is not new. However, in recent years it has gained added impetus. There are many reasons for this added interest--and many reasons for added concern about possible nutrient antagonisms. Miller \& Payne (I964) have discussed some of the factors affecting nitrogen balance and Blaxter (1964) has reviewed the work on factors affecting energy utilization. Both of these fields have obvious application in the developing areas of the world and are of immediate concern. They are also of great economic importance in animal husbandry. Recent interest in lipid metabolism and the association of abnormalities of lipid metabolism with coronary atherosclerosis has led us into the field of interrelationships between fat, fatty acids and other dietary components. Widespread institution of food enrichment programmes is another reason for concern.

For many years it has been recognized that interrelationship also existed between the vitamins and other micro-nutrients. This was intensively studied during the era of vitamin discoveries. However, owing to the poor definition of dietary constituents, many of the early results were difficult to interpret. When purified, semi-synthetic diets were available, attention changed to a study of the functions of individual vitamins and interest in interrelationships lagged, with a few notable exceptions. The cycle is now repeating itself and again we are showing great interest in these interrelationships.

When we deal with the micro-nutrients and particularly with the vitamins, we face certain problems that are not as pressing when protein or energy metabolism is being studied. One of the major problems we face, and I am sure that Dr Campbell will 
discuss this in his paper, is the selection of criteria for measurement. Traditionally body-weight gain and food conversion efficiency ratio have been employed as criteria in animal studies. Indeed these are eminently suitable criteria in the field of animal husbandry or at least in that portion of it concerned with meat production. But in human nutrition, we tend to look toward biochemical alterations with the hope that they may prove to be more sensitive criteria. Frequently 'tissue saturation' as measured by the 'load test' has been considered a suitable measure of nutritional status.

These three types of measurement do not necessarily give the same answer. This may be illustrated by some data we have accumulated on vitamin $\mathrm{B}_{6}$ in the rat. Some years ago we were interested in factors affecting tissue levels of the vitamin. We noted that, when pyridoxine hydrochloride was administered by daily subcutaneous injection to rats otherwise deprived of the vitamin, maximal liver vitamin $B_{6}$ concentrations were obtained at a dosage of $15^{-25} \mu \mathrm{g} /$ day; body-weight gain was still increasing at $25 \mu \mathrm{g} /$ day. Recently we have carried out a similar type of study, this time comparing blood transaminase activities and body-weight gain. We obtained a maximal body-weight response with about $40 \mu \mathrm{g}$ pyridoxine hydrochloride/day, but transaminase activity was still increasing at the $80 \mu \mathrm{g}$ level. One wonders then which criteria should be used in studying interrelationships--ability to store or retain the nutrient (seen here at $20-25 \mu \mathrm{g} /$ day), ability to increase body-weight ( $40 \mu \mathrm{g} /$ day), or maximal activity of an enzyme dependent upon the nutrient (in excess of $80 \mu \mathrm{g} /$ day). One might, and should, also consider the use of histological criteria.

The other problem we face is obvious-what should we study. With more than forty dietary constituents now established as being utilized by one species or another, the number of combinations that might be studied is virtually infinite.

It has frequently been said that the science of nutrition is in its infancy. In the area of nutrient interrelationships I am sure that we must agree this is true. But from the programme of this Symposium, I am sure that we will also agree that it is rapidly coming of age.

\section{REFERENCES}

Blaxter, K. L. (1964). Proc. Nutr. Soc. 23, 3.

Miller, D. S. \& Payne, P. R. (1964). Proc. Nutr. Soc. 23, 11.

\section{Dietary factors affecting vitamin requirements}

\section{By J. A. Campbell*, Division of Food Technology and Nutrition, Faculty of Agricultural Sciences, American University of Beirut, Beirut, Lebanon}

Vitamin requirements are influenced by many factors, one of which is the content or proportion of other nutrients in the diet. This is probably to be expected since vitamins are directly involved in the metabolism of these nutrients. A glance at the literature indicates that studies have been made on the effect of most nutrients on

\footnotetext{
*Permanent address: Food and Drug Directorate, Department of National Health and Welfare, Ottawa, Canada.
} 